$1-1-1964$

\title{
Influence of selected rainfall characteristics on runoff volume
}

Vernon O. Shanholtz

W.H. Dickerson

Follow this and additional works at: https://researchrepository.wvu.edu/ wv_agricultural_and_forestry_experiment_station_bulletins

\section{Digital Commons Citation}

Shanholtz, Vernon O. and Dickerson, W. H., "Influence of selected rainfall characteristics on runoff volume" (1964). West Virginia Agricultural and Forestry Experiment Station Bulletins. 497T.

https://researchrepository.wvu.edu/wv_agricultural_and_forestry_experiment_station_bulletins/656 @ WVU. It has been accepted for inclusion in West Virginia Agricultural and Forestry Experiment Station Bulletins by an authorized administrator of The Research Repository @WVU. For more information, please contact ian.harmon@mail.wvu.edu. 




\section{BULLETIN $497 T$}

\section{INFLUENCE OF \\ SELECTED RAINFALL \\ CHARACTERISTICS ON RUNOFF VOLUME}

WEST VIRGINIA UNIVERSITY AGRICULTURAL EXPERIMENT STATION IN COOPERATION WITH UNITED STATES DEPARTMENT OF AGRICULTURE 


\section{THE AUTHORS}

V. O. Shanholtz, formerly Graduate Assistant in Agricultural Engineering at West Virginia University, is now Hydraulic Engineer, Soil and Water Conservation Research Division, Agricultural Research S e rvi ce, U. S. Department of Agriculture, Blacksburg, Va. IV. H. Dickerson is Agricultural Engineer, West Virginia University Agricultural Experiment Station.

\section{ACKNOWLEDGMENTS}

The authors are grateful for the valuable advice of J. L. McGuinness, Statistician, Agricultural Research Service, Coshocton, Ohio, and for the data used in this study provided from the North Appalachian Experimental Watershed, Coshocton, Ohio.

\section{West Virginia University}

Agricultural Experiment Station

College of Agriculture, Forestry, and Home Economics

A. H. VanLandingham, Director

Morgantown

In CoOperation with

United States Departanent of Agriculture 


\section{Contents}

INTRODUCTION

PREVIOUS WORK ........... . 6

SAMPLING PROCEDURE . . . . . . 7

Moorefield Data ..... . . . . . . . 7

Coshocton Data ............. 7

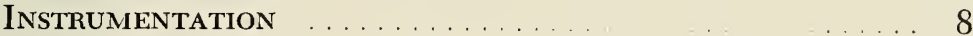

StORM Event ....................... 8

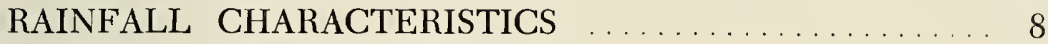

Total Rainfall .................... 9

Maximum Intensities for Selected Time Intervals ... . 9

Average Intensity for the Storm Event ... . . . . . . . 9

Average Intensity for the Rain Period . . . . . . . . . . 9

Weighted Storm Intensities ................ 9

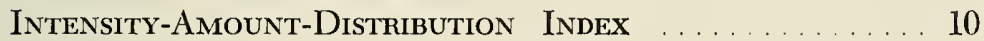

Pattern Index ....................... 10

Weighted Pattern Index ................... 10

Total Storm Energy ................... 10

Total Energy x 30-minute Maximum Intensity . . . . . . 11

Storm Duration ..................... 11

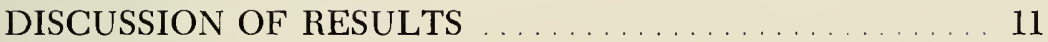

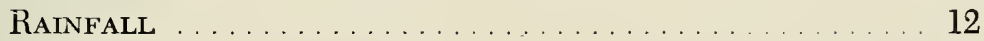

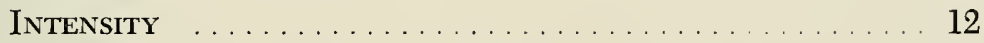

PAtTERN ........................... 13

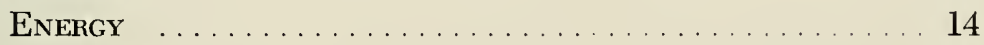

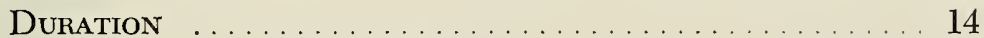

Product and Quotient Terms ................. 14

Multiple Regression Analysis ................ 15

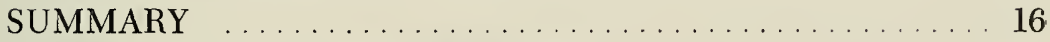

NEED FOR FUTURE RESEARCH . . . . . . . . . . . . . . 17

REFERENCES ........................ 18

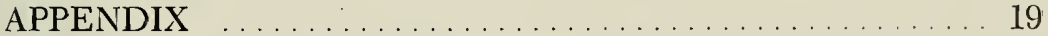

A List of Symbols and Abbreviations . . . . . . . . . . . . 19

B Sample Calculations . . . . . . . . . . . . . . . . . 20 
Digitized by the Internet Archive in 2010 with funding from

Lyrasis Members and Sloan Foundation 


\section{Influence of Selected Rainfall Characteristics on Runoff Volume}

\section{INTRODUCTION}

V. O. SHANHOLIZ and W. H. DICKERSON

AINFALL-RUNOFF relationships constitute one of the perplexing problems in hydrology. Attempts have been made, with varying success, to evaluate the relationship between these phenomena. Despite these attempts, the question still remains: Given a specific rainfall, how much will appear as runoff?

Many of the factors that modify the rainfall-runoff relationship are known. These often are grouped into two categories-rainfall factors and watershed factors, and they may act jointly or individually during any one storm; however, it is difficult to assign them a numerical value which will accurately reflect their influence on runoff.

The rainfall-runoff relationship often has been studied under two general concepts-large watersheds and small watersheds. Although the basic factors that influence the rainfall-runoff relationship are probably the same for both types of watersheds, the influence of the individual factors or the way they act in combination may be quite different-for example, rainfall during a particular storm may be fairly uniform over a small watershed, say of 10 acres, but it is rarely uniform over a watershed of several thousand acres.

The basic objective of this investigation was to bring together in one group rainfall characteristics that may influence the runoff regimen. The study was limited to the influence of selected rainfall characteristics on the volume of surface runoff from watersheds of 10 acres or less. Point rainfall was used to represent areal distribution. No attempt was made to investigate watershed factors in this study.

Rainfall characteristics examined included: (a) total amount, (b) intensity, (c) distribution, (d) pattern, (e) energy, and (f) duration. A numerical value was assigned to each factor, and its relative influence on runoff was determined by statistical techniques. Also, product and quotient terms, as suggested from the analyses of the individual factors, were examined in an attempt to determine interrelationships 
existing between the individual rainfall characteristics. An important factor that was not considered was antecedent precipitation. This omission was dictated by the lack of data. Kohler, et al. (5) have reported extensive studies on the influence of this parameter on runoff.

Two samples of data were secured. The first was obtained from the North Appalachian Experimental Watershed, maintained by the Agricultural Research Service (ARS), Coshocton, Ohio, and the second from the research watersheds at Moorefield, West Virginia, which are maintained by ARS in cooperation with the West Virginia University Agricultural Experiment Station. Analyses of the data were carried out separately and tested for comparative purposes.

\section{PREVIOUS WORK}

Many studies of rainfall-runoff relationships have had as their objective the development of a method by which a single or combination of easily measured rainfall characteristics can be used to estimate rate or volume of runoff. Aside from total rainfall, intensity is one of the most easily measured characteristics, and, as might be expected, much work has been done to relate it to runoff. In part, these efforts stem from the numerous studies of infiltration.

Young (12) pointed out that the relationship between runoff and rainfall is dependent upon many factors, few of which remain constant. Foster (2) suggested that intensity parameters need to have the following properties-improved characterization of intensity, ease of computation, and universal application. In a study of nine indices of rainfall, Foster concluded that the best single index of rainfall intensity was obtained from the 30-minute maximum intensity. However, longer periods were not used in his study.

Neal (7) studied the problem by classifying storm events according to intensity and antecedent rainfall. Schiff (8) reported work on intensity and storm pattern, and Minshall (6) on storm pattern and antecedent moisture conditions. Barnett's (1) work was aimed at deriving a prediction equation based on rainfall characteristics for erosion losses. Since erosion and runoff are undoubtedly closely related, this might be expected to apply to the problem under investigation, but Barnett found no single rainfall characteristic to be satisfactory for predicting erosion from a given storm for the condition studied.

One of the most frequently used statistical techniques for studying rainfall-runoff relationships and other similar problems has been that of multiple regression. Harris, et al. (3) and Snyder (10) have outlined several difficulties in applying regression analyses to hydrologic data. According to these investigators, two critical problems are errors in 
measuring independent and dependent variables and high intercorrelation that may exist between the independent variables. Because of these, extreme care must be taken in assigning statistical significance to regression coefficients and in assessing the influence of corresponding independent variables in the prediction of some dependent variable.

\section{SAMPLING PROCEDURE}

The primary interest of this study was the influence of rainfall characteristics on runoff volume; therefore, the first criterion of storm selection was that runoff must occur. This type of selection did not give information on threshold conditions necessary for runoff. A second criterion was that all topographic and watershed factors remain essentially constant. Land management, slope, aspect, soils, and cover are included in this category. The ultimate aim was to have all variables, exclusive of rainfall characteristics, constant. Under these conditions the relative influence of the parameters being investigated could be more easily assessed.

\section{Moorefield Data}

Moorefield Watershed No. 2 (9.73 acres) was selected as the test watershed. This watershed was in fair pasture and the grazing load was controlled. Little variability, due to grazing, occurred from changing vegetative cover or soil structure. Litz shaly silt loam is the predominant soil type. These soils are shallow and, due to their shallow depth, have a low potential water-holding capacity. Other topographic and watershed factors remained reasonably constant throughout the test period.

\section{Coshocton Data}

At Coshocton, experience has shown that most runoff events from small areas were from corn land, and occurred early in the growing season. As a consequence, areas in corn were chosen in preference to areas planted in pasture or other crops. An examination of the data showed an insufficient number of events available from any one corn watershed, since corn appears only once in the standard four-year rotation. This required the selection of four different watershed areas in order to obtain a suitable number of storms for the final sample. The selected watersheds with their respective areas were: W-106 (1.56 acres); W-110 (1.27 acres); W-115 (1.61 acres); and W-118 (1.96 acres).

Soils on the selected watersheds are predominantly Keene and Muskingum silt loams. During the growing season, the hydrologic 
characteristics of these two soil types tend to be similar. For this reason, and to hold the cover afforded by the growing corn relatively "constant," only those storms occurring in June were used.

\section{Instrumentation}

Rainfall measurements were made with recording rain gages with 12-hour time scales. Since the areas were very small with gentle topography, point rainfall was assumed to represent the watershed mean rainfall. Runoff measurements were made with H-type flumes equipped with FW-1 recorders. Ephemeral streamflow occurred during the test period.

\section{Storm Event}

In this study, only that part of the rainfall believed to directly influence the runoff hydrograph was considered. As long as runoff was occurring, any rainfall within that period was considered. When runoff ceased, subsequent rainfall was excluded. The most difficult question involved the rainfall immediately prior to the runoff event.

The criteria for establishing the time when storm rainfall began involved rough approximations of lag time and minimum infiltration rates for the watersheds. For all of the watersheds, the average lag time was estimated to be 10 minutes and the minimum infiltration rate to be approximately 0.1 inch per hour. These values were used to establish the following criteria for including or excluding storm rain antecedent to the time runoff starts: (1) all rain falling prior to the time of runoff starting but at a time greater than the lag time of 10 minutes was excluded; and (2) all rain falling during the lag time of 10 minutes was excluded when all intensities were less than 0.10 inch per hour.

In many storm events, the rainfall intensity pattern will occur in such a manner as to cause multi-peak hydrographs. Multi-peak hydrographs were separated into different storm events only when the recession limb reached a point equivalent to 0.01 foot gage height $(0.0001$ inch per hour).

With these criteria established, the available data were sorted and tabulated. From the final tabulations, 31 runoff events were selected from the Moorefield No. 2 pasture watershed and 77 from the Coshocton corn watersheds. Table 1 is a segment of the data from both the Moorefield and Coshocton watersheds, illustrating the range covered by the runoff events.

\section{RAINFALL CHARACTERISTICS}

A list of symbols and abbreviations used in this bulletin is given in Appendix A. The analytical procedures involved in obtaining the 
Table 1. Selected Runoff Events from the Moorefield Pasture Watershed and the Coshocton Corn Watersheds

\begin{tabular}{c|c|c|c|c|c}
\hline $\begin{array}{c}\text { Location } \\
\text { and } \\
\text { Event No. }\end{array}$ & $\begin{array}{c}\text { Rainfall } \\
\text { (Inches) }\end{array}$ & $\begin{array}{c}\text { Runoff } \\
\text { (Inches) }\end{array}$ & $\begin{array}{c}\text { Location } \\
\text { and } \\
\text { Event No. }\end{array}$ & $\begin{array}{c}\text { Rainfall } \\
\text { (Inches) }\end{array}$ & $\begin{array}{c}\text { Runoff } \\
\text { (Inches) }\end{array}$ \\
\cline { 1 - 3 } $\begin{array}{c}\text { Coshocton } \\
1\end{array}$ & 0.52 & 0.0118 & $\begin{array}{c}\text { Moorefield } \\
1\end{array}$ & 0.57 & 0.0054 \\
2 & 1.45 & 0.4017 & 2 & 0.85 & 0.1092 \\
3 & 0.99 & 0.5900 & 3 & 1.09 & 0.4520 \\
4 & 3.18 & 1.0539 & 4 & 0.32 & 0.0232 \\
5 & 0.48 & 0.0376 & 5 & 1.37 & 0.3452 \\
6 & 0.21 & 0.0034 & 6 & 0.25 & 0.0003 \\
7 & 1.12 & 0.2220 & 7 & 2.15 & 0.2891 \\
8 & 3.63 & 1.9045 & 8 & 0.73 & 0.0019 \\
\hline
\end{tabular}

numerical estimates of the various rainfall characteristics are given in Appendix B.

The primary characteristics are defined as follows:

\section{Total Rainfall (P)}

The total rainfall is the amount that fell from the beginning to the end of the storm, as previously defined on page 8 .

\section{Maximum Intensities for Selected Time Intervals $\left(\left.\left.\right|_{2} \ldots\right|_{2+10}\right)$}

The selected time intervals were $2,5,10,15,20,30,60,90,120$, 150, and 240 minutes. The maximum rainfall for each of these periods was determined and the corresponding intensity computed.

\section{Average Intensity for the Storm Event $\left(\mathrm{I}_{\mathrm{A} \text { Y } \mathrm{GST}}\right)$}

The average intensity for the storm was the total rainfall divided by the duration of the event.

\section{Average Intensity for the Rain Period ( $\left.I_{A Y G R P}\right)$}

In many storms there are short periods of zero rainfall. The average intensity for the rain period was defined, therefore, as total rainfall divided by the time in which rain actually occurred.

\section{Weighted Storm Intensities $\left(\mathrm{I}_{\mathrm{WT}_{1}} \& \mathrm{I}_{\mathrm{WT}_{2}}\right)$}

Two weighted intensities were used in this study. The first was found by summing the product of intensity and rainfall per time interval and dividing this sum by total rainfall.

For the computation of the second weighted intensity, the total rainfall was partitioned into quarters by chronological order. The time 
required for each partitioned rainfall was determined and the intensity for the four corresponding periods computed. The second weighted intensity was the arithmetic average of these four intensities.

\section{Intensity-Amount-Distribution-Index}

All rainfall occurs at a rate or intensity greater than zero. The lower limit of rainfall amount will be fixed by the maximum storm intensity for a specified duration. The upper limit will be the total rainfall (all rainfall occurring at a rate greater than zero). The amount of rainfall will progressively decrease from the total rainfall at zero intensity to zero rainfall at the maximum storm intensity. The Intensity-Distribution may be characterized by arbitrarily selecting rainfall rates between zero and the maximum storm intensity. The rainfall rates (base intensities) used for this study were: $0.0,0.3,0.5,1.0$, $1.5,2.0,3.0,4.0$, etc., inches per hour. The computational procedure followed is illustrated in Figure Bl.

By log transformation, as suggested by Hutchinson, et al. (4), a plot of base intensity versus amount resulted in a straight line (Figure B1). For the purpose of this study, the slope of this regression line is defined as the Intensity-Amount-Distribution Index.

\section{Pattern Index (PI)}

If the time and amount for a given storm are computed on an accumulated percentage basis and plotted as accumulated time versus accumulated amount, the pattern of the storm will be characterized (Figure B2). For an advanced pattern, the curve will rise very sharply during the early part of the storm. For the delayed pattern, the curve will rise sharply during the last portion of the storm. The pattern index was defined as the area under the curve of accumulated time versus accumulated amount. A value of 0.3 would represent a delayed storm pattern, 0.8 an advanced pattern, and 0.5 would represent an intermediate pattern.

\section{Weighted Pattern Index $\left(\mathrm{PI}_{\mathrm{TT}}\right)$}

In the pattern index described, undue emphasis was placed on long periods of low intensity rainfall. The weighted pattern index was defined as the accumulated sum of the product of the intensity for each given time interval and the area under the pattern curve for that interval. This index has the effect of weakening the influence of very low intensity periods.

\section{Total Storm Energy (E)}

This characteristic was defined by Wischmeier, et al. (11) as: $\mathrm{E}=916+331(\log \mathrm{I})$, where intensity $(\mathrm{I})$ is expressed in inches per 
hour and energy (E) as units of foot tons per acre-inch. This characteristic was developed primarily as an estimator of soil loss or erosion. However, the amount of soil loss may be related to the amount of runoff. The energy of the raindrops under certain conditions may cause puddling or sealing of the soil surface. This would greatly reduce the infiltration rate.

\section{Tota! Energy x 30-minute Maximum Intensity $\left(\left.E \cdot\right|_{30}\right)$}

Wischmeier, et al. (11) found this to be the best single parameter for predicting soil loss from fallow plots. This product term measures the interaction of the two individual variables.

\section{Storm Duration (D)}

The duration parameter used is defined as the total storm duration in minutes.

\section{DISCUSSION OF RESULTS}

All analyses, including the numerical estimates of the rainfall characteristics and product and quotient terms, were determined with an IBM 1620 computer.

Regression analyses after Snedecor (9) were made between the selected rainfall characteristics and runoff volume for both sets of data. Statistical tests were then made to determine if the two sets of data could be combined and analyzed as one large sample. The correlation coefficients for the different models from the two samples were tested for "likeness" by methods outlined by Snedecor. These tests indicated that the two samples were drawn from different populations, and, therefore, could not be combined.

Differences may possibly be explained by different watershed characteristics such as soil type, depth, drainage density, slope, cover, and watershed geographic location. Another contributing factor may be the length of record. The Coshocton sample was selected from a record of approximately 30 years, while the Moorefield record was limited to 4 years. The longer the record, the greater the chance for high runoffproducing storms. These storm types tend to increase the correlation between total rainfall and runoff volume because runoff volume approaches total rainfall. These storm types were noticeably absent from the Moorefield sample.

A summary of the regression analyses for both samples of data is given in Table 2. A discussion of this table by major rainfall characteristics follows. 
Table 2. Summary of Statistics for the Regression of Runoff Volume on Selected Rainfall Characteristics

\begin{tabular}{|c|c|c|c|c|c|}
\hline \multirow[t]{2}{*}{ Characteristic } & $\begin{array}{c}\text { Coshocton } \\
\text { data } \\
(n=77)\end{array}$ & $\begin{array}{c}\text { Moorefield } \\
\text { data } \\
(\mathrm{n}=31)\end{array}$ & \multirow[t]{2}{*}{ Characteristic } & $\begin{array}{c}\text { Coshocton } \\
\text { data } \\
(\mathbf{n}=77)\end{array}$ & $\begin{array}{c}\begin{array}{c}\text { Moorefield } \\
\text { data }\end{array} \\
(\mathrm{n}=31)\end{array}$ \\
\hline & $\mathrm{r}^{2}(\%)$ & $\mathrm{r}^{2}(\%)$ & & $\mathrm{r}^{2}(\%)$ & $\mathrm{r}^{2}(\%)$ \\
\hline I. $\mathrm{P}$ & 76.18 & 54.02 & 22. $\mathrm{E} \cdot \mathrm{I}_{30}$ & 65.83 & 34.26 \\
\hline 2. $I_{A Y G S T}$ & 0.13 & 1.33 & 23. $\mathrm{PI} \cdot \mathrm{SL}$ & 1.88 & 1.14 \\
\hline 3. $I_{A V G R P}$ & 0.10 & 1.10 & 24. $\mathrm{Pl} \cdot \mathrm{I}_{\mathrm{WT} 1}$ & 10.18 & 0.90 \\
\hline 4. $\mathrm{I}_{2} \ldots$ & 19.22 & 0.80 & 25. $\mathrm{P} 1 \cdot \mathbf{1}_{\mathrm{WT}}$ & 10.15 & 1.17 \\
\hline 5. $\mathrm{I}_{5}$ & 24.42 & 2.66 & 26. $\mathrm{PI} \cdot \mathrm{I}_{30}$ & 64.80 & 17.31 \\
\hline 6. $I_{10}$ & 32.58 & 2.90 & 27. $P I \cdot I_{111}$ & 32.95 & 0.44 \\
\hline 7. $I_{15}$ & 42.39 & 6.62 & 28. PI/1 100 & 9.67 & 11.16 \\
\hline 8. $\mathrm{I}_{20}$ & 50.11 & 7.73 & 29. $\mathrm{PI} / \mathrm{I}_{11}$ & 7.84 & 4.54 \\
\hline 9. $\mathrm{I}_{30}$ & 56.33 & 12.45 & 30. $\mathrm{PI} \cdot \mathbf{1}_{\mathrm{AVGST}}$ & 0.08 & 1.74 \\
\hline 10. $I_{60}$ & 68.37 & 29.66 & 31. $S L \cdot 1_{W T 1}$ & 3.06 & 2.69 \\
\hline I1. $I_{90}$ & 69.53 & 35.30 & 32. $\mathrm{SL} \cdot \mathrm{I}_{60}$ & 34.93 & 5.11 \\
\hline 12. $I_{1 \geq 0}$ & 69.99 & 39.51 & 33. $\mathrm{SL} \cdot \mathrm{I}_{\mathrm{WT}}$ & 3.99 & 1.07 \\
\hline 13. $I_{150}$ & 70.34 & 41.38 & 34. $\log \left(\mathrm{P} \mathbf{1} / \mathbf{1}_{60}\right)$ & 35.93 & 21.61 \\
\hline 14. $\mathbf{1}_{240}$ & 72.54 & 40.23 & 35. $\mathbf{1}_{2} \cdot \mathrm{D} \ldots \ldots$ & 54.74 & 30.97 \\
\hline 15. SL & 2.60 & 1.76 & 36. $I_{3} \cdot \mathrm{D}$ & 52.09 & 31.32 \\
\hline 16. PI & 6.43 & 0.19 & 37. $\mathrm{I}_{10} \cdot \mathrm{D}$ & 56.91 & 29.63 \\
\hline 17. $\mathrm{E}$ & 74.31 & 44.98 & 38. $1_{10} \cdot \mathrm{D}$ & 62.88 & 33.37 \\
\hline 18. $\mathrm{D}$ & 39.06 & 23.04 & 39. $I_{20} \cdot \mathrm{D}$ & 67.02 & 36.24 \\
\hline 19. $\mathrm{I}_{\mathrm{WT} 1}$ & 6.97 & 0.15 & 40. $\mathrm{I}_{30} \cdot \mathrm{D}$ & 68.18 & 40.46 \\
\hline 20. $\mathrm{I}_{\mathrm{WT} 2}$ & 3.20 & 0.59 & 41. $\mathrm{I}_{80} \cdot \mathrm{D}$ & 71.87 & 43.14 \\
\hline 21. $P I_{W T}$ & 21.72 & 0.09 & & & \\
\hline
\end{tabular}

\section{Rainfall}

Data in Table 2 reveal that total rainfall exhibited the highest correlation with runoff volume for both samples. Intuitively, this would be expected since by definition rainfall must be great enough to produce runoff. All other things being equal, the greater the rainfall, the greater the potential runoff volume.

\section{Intensity}

The average storm period and average rain period intensity provide no workable relationships with runoff volume. Only 0.13 per cent and 0.10 per cent, respectively, of the sums of squares may be attributable to the regression of runoff volume on these factors. These findings support Foster's (2) study of nine intensity indices.

The maximum intensities for selected time intervals show an increasing correlation with runoff volume as the intensity period increases for both the Moorefield and Coshocton data. The correlation between the respective intensity periods and runoff volume increases, primarily, 
because the value of the maximum intensity characteristics approaches the magnitude of the storm rainfall.

Further inspection of items 4-14 in Table 2 shows that the increase in the correlation existing between runoff volume and maximum storm intensity plateaus at approximately the 60-minute maximum intensity $\left(I_{60}\right)$ for both samples of data. Relative increases from $I_{60}$ to $I_{240}$ have little practical significance (items 11-14, Table 2).

Once it is established that a number of independent variables are related to some dependent variable, it is often desirable to determine the value of the independent variables acting as a group in predicting this dependent variable. Such a relationship or model may be developed by methods of multiple regression. A requirement of multiple regression is that the independent variables not be interrelated. Items 4-14, Table 2, are highly intercorrelated, hence only one of these values should be used in developing a prediction equation of several independent factors. The question now posed-Which maximum intensity period best reflects the influence of intensity on runoff volume? Inspection of items 4-14, Table 2, would indicate that the $I_{60}$ parameter would give the best average estimate. However, many factors may act either individually or jointly to change the above estimate. As a consequence, more research is needed to determine the intensity period for each storm that will best reflect the role of intensity in producing surface runoff. This need is reiterated on page 17 .

Two weighted intensities were used in an attempt to obtain a better definition of the storm intensity pattern. For these parameters, the coefficient of determination $\left(\mathrm{r}^{2}\right)$ was significantly less than for the 60 -minute maximum intensity $\left(\mathrm{I}_{60}\right)$.

The intensity-amount-distribution index (SL), which may be considered analogous to a flow duration curve, appeared to be of little value in runoff prediction. This index does reflect seasonal patterns and thus may be of some value in annual runoff predictions for larger watersheds.

\section{Pattern}

As pointed out by Minshall (6) and Schiff ( 8 ), the pattern of a given storm may have a marked influence on the amount of runoff. For the Coshocton sample, 6.43 per cent of the sums of squares could be attributed to the regression of runoff volume on storm pattern. For the Moorefield sample, only 0.19 per cent of the runoff volume sums of squares could be attributed to the regression of runoff volume on storm pattern. These values indicated no workable relationship between runoff volume and storm pattern. 
Table 3. Classification of Storm Patterns

\begin{tabular}{l|c|c|c}
\hline \multicolumn{1}{c|}{ Location } & $\begin{array}{c}\text { Delayed } \\
(\mathbf{0 . 0 0 - 0 . 3 9 )}\end{array}$ & $\begin{array}{c}\text { Intermediate } \\
\mathbf{( 0 . 4 0 - 0 . 5 9 )}\end{array}$ & $\begin{array}{c}\text { Advanced } \\
\mathbf{( 0 . 6 0 - 1 . 0 0 )}\end{array}$ \\
\hline Coshocton & 2 & 44 & 31 \\
Moorefield & 1 & 9 & 21 \\
\hline
\end{tabular}

Several factors may tend to mask the influence of this parameter. First, considering a typical storm event, relatively long periods of low intensities ( $0.10 \mathrm{in} . / \mathrm{hr}$. or less) may occur. The influence of these periods was over-emphasized due to the definition of the pattern index. Secondly, most of the storm events of this study fell into the same general pattern. This is illustrated in Table 3, where the storms are grouped as either delayed, intermediate, or advanced.

An attempt to lessen the influence of low intensity periods was made by computing a weighted pattern index $\left(\mathrm{PI}_{\mathbf{W T}}\right)$. In the resulting regression analysis, $\mathrm{r}^{2}$ was found to increase from 6.4 per cent to 21.7 per cent for the Coshocton data. For the Moorefield data, a change from a negative to positive correlation occurred with $r^{2}$ retaining approximately the same magnitude. These were significant relative changes but are still of little practical value.

\section{Energy}

Exclusive of total rainfall, energy was the best single variate studied. The coefficient of determination was found to be 74 per cent for the Coshocton data and 45 per cent for the Moorefield data. An intercorrelation of 0.99 existed between total rainfall and energy. This is to be expected, since rainfall intensity is a major factor in the derivation of the energy index. The product term of energy and 30-minute maximum intensity $\left(\mathrm{E} \cdot \mathrm{I}_{30}\right)$ gave an $\mathrm{r}^{2}$ equal to 65.8 per cent for the Coshocton data and 34.3 per cent for the Moorefield data.

\section{Duration}

Storm duration reflected statistical significance at the 1 per cent level. Strong intercorrelation existed between total rainfall and the duration of the storm; hence, caution must be followed in interpreting the influence of duration on runoff volume. The principal difficulty would result from a multiple regression analysis, where the influence of various parameters would need to be assessed.

\section{Product and Quotient Terms}

A number of product and quotient models were constructed in an attempt to reflect interrelationships existing between specific rain- 
fall characteristics, e.g., 60-minute maximum intensity times storm pattern index $\left(\mathrm{I}_{60} \cdot \mathrm{PI}\right)$. These product and quotient terms are referred hereafter as interaction terms since they represent the mutual retion of two or more independent variables. Selected results of the alyses of the above models are summarized in items 22 through 41 Table 2.

The product of duration and maximum intensity (items 35-41, ble 2), which was used to reflect excess rainfall, showed an increasing rrelation with increasing intensity period. Some relative improvement noted over maximum intensity alone for both sets of data.

A rather high correlation was noted for the 60-minute maximum ensity and storm pattern index $\left(\mathrm{I}_{60} \cdot \mathrm{PI}\right)$ interaction parameter. This $\mathrm{m}$ accounts for 64.8 per cent of the runoff volume sum of squares. comparison was made between the mutual influence of the interion term $I_{60} \cdot$ PI and the influence of the individual factors $I_{60}$ and on runoff volume. This comparison revealed that considerable impruvement was gained over PI alone $\left(\mathrm{r}^{2}=6.4\right.$ per cent), but little improvement was noted for the $I_{60}$ factor $\left(r^{2}=68.4\right.$ per cent $)$. In general, relative increases resulted in the percentage of sums of squares attributable to the regression of runoff volume on interaction terms involving the storm pattern index (PI) and the intensity-amountdistribution index (SL). In no instance did the interaction terms contribute more information in a single prediction equation than did total rainfall. Most of the interaction terms studied showed low correlations with runoff volume. The low correlations may be due to several factors: (1) The inability to numerically represent the interrelationship between two variables by a simple product or quotient combination. Perhaps a different method of numerically characterizing interrelations such as squaring, logarithms or additive combinations is needed. (2) No measurable interrelation may exist. (3) Measurement of the independent variables is not sufficiently accurate to detect interrelations. Further study is needed to investigate other possibilities for numerically representing the combined reaction of two or more rainfall characteristics and their influence on runoff volume.

\section{Multiple Regression Analysis}

In examining the unknown deviations from linear regression, several groups of parameters were analyzed simultaneously by methods of multiple regression. One group consisted of $\mathrm{P}, \mathrm{I}_{60}, \mathrm{D}, \mathrm{PI} / \mathrm{I}_{60}, \mathrm{PI}, \mathrm{E}$ and LOG $\left(P I / I_{60}\right)$. This group gave an $R^{2}$ of 78 per cent for the Coshocton data and 67 per cent for the Moorefield data. Comparable values from the linear regression of total rainfall with runoff volume were 76 per cent and 54 per cent, respectively. A test of significance 
of the partial regression coefficients indicated no significant contribution from the addition of the six independent variables.

A second group of parameters-P, $\mathrm{I}_{60}, \mathrm{PI} \cdot \mathrm{I}_{60}$ and $\mathrm{D}$-showed no improvement over total rainfall.

\section{SUMMARY}

The influence of selected rainfall characteristics on surface runoff volume was investigated. Data for the study were obtained from the Coshocton, Ohio, and Moorefield, West Virginia, ARS Research Stations.

The objective was to bring together in one group rainfall characteristics which may influence the runoff regimen. A numerical value was established for each and their relative influence was determined by linear and multiple regression analyses.

The parameters studied included total rainfall, intensity, distribution, pattern, energy, duration, and interaction terms. As was expected at the initiation of the study, total rainfall gave the best single estimate of runoff volume. The energy of the storm raindrops as defined by Wischmeier, et al. (11) estimated runoff with about the same accuracy as total rainfall. A very high intercorrelation $(r=0.99)$ existed between energy and total rainfall.

The 60-minute maximum intensity period $\left(\mathrm{I}_{60}\right)$ for both the Moorefield and Coshocton data was found to give the best average estimate of runoff of all the intensity periods studied. An $\mathrm{r}^{2}$ of 68 per cent and 30 per cent was noted for the Coshocton and Moorefield data, respectively. The intensity-amount-distribution index (SL) indicated no workable correlation with runoff volume. The pattern index (PI) indicated no workable relationship for either the Coshocton or Moorefield data. A weighted pattern index $\left(\mathrm{PI}_{W_{\mathrm{T}}}\right)$, which tended to dampen the influence of periods of low intensity, showed considerable improvement over the pattern index, resulting in an increase in $\mathrm{r}^{2}$ from 6.4 per cent to 21.7 per cent for the Coshocton data. The only visible change in the Moorefield data was a change in sign of the correlation coefficient. The storm duration parameter (D) showed statistical significance at the 1 per cent level, but this was due primarily to the intercorrelation between total rainfall and length of storm.

Product terms involving storm duration and maximum intensity contributed more information than the individual parameters. The $I_{6,6} \cdot D$ factor accounted for 72 per cent of the runoff volume sums of squares. Of the numerous interaction terms involving the PI and SL parameters, only two, $\mathrm{SL} \cdot \mathrm{I}_{60}$ and $\mathrm{PI} \cdot \mathrm{I}_{60}$, indicate possible importance.

The analysis of rainfall characteristics indicated that no single rainfall characteristic could be used to satisfactorily estimate runoff 
volume. Errors of 20 to 25 per cent would result from the Coshocton sample, whereas errors of 50 per cent or greater could be expected from the Moorefield sample. The study did indicate that the intensity, amount, distribution, pattern and energy of a given storm influence the magnitude of the resulting runoff. These characteristics could be represented by numerical values.

It must be recognized that watershed conditions play a major role in conjunction with rainfall characteristics in producing runoff from any given storm event. By including appropriate parameters to reflect the influence of these interrelations in the rainfall-runoff equation, the error could possibly be reduced significantly.

\section{NEED FOR FUTURE RESEARCH}

This study has disclosed the need for further research in two general fields-first, a systematic approach to define threshold conditions, i.e., conditions necessary for runoff to occur; and second, a method to determine the period which best reflects the influence of intensity on surface runoff for all storms, regardless of duration.

\section{Threshold Conditions}

In the aforementioned analysis the influence of selected rainfall characteristics on surface runoff was investigated. The data were limited to runoff-producing storms. No attempt was made to define conditions necessary for runoff to occur. This places a definite limitation on the use of the results for prediction purposes. For many hydrologic problems requiring an estimate of rumoff volume, it is not known whether the storm in question will produce surface runoff. Determination of these conditions is left to the researchers' experience and judgment. Once it is established that runoff will occur, then procedures such as those outlined may be used to predict the volume. There is need for a systematic approach to define threshold conditions.

\section{Storm Intensity}

A period which best reflected the influence of maximum intensity on runoff was determined (page 13). At best, this period is probably no more than a weighted average, i.e., the period is influenced, to some degree, by the length of storm and the number of events falling within a given duration group. This being the case, there is about a 50 per cent chance in runoff predictions that the wrong intensity period will be employed.

To lessen these errors, a relationship is needed which is independent of both storm duration and grouping. This, hopefully, may be 
accomplished by the selection of a very large sample which may be segmented into a number of duration groups of sufficient size for statistical interpretations.

From these duration groupings, a regression analysis of maximum intensity versus runoff volume with the influence of total rainfall removed may be determined. From this analysis a regression line through the points of maximum correlations may be established. This relationship may then be used to compute the intensity parameter needed in the rainfall-runoff relation.

\section{REFERENCES}

1. Barnett, A. P. "How Intense Rainfall Affects Runoff and Soil Erosion." Agricultural Engineering, v. 39, pp. 703-707 (November, 1958).

2. Foster, W. D. "A Comparison of Nine Indices of Rainfall Intensity." American Geophysical Union Transactions, v. 31, pp. 894-900 (December, 1950).

3. Harris, B., Sharp, A. L., Gibbs, A. E., and Owen, W. J. "An Improved Statistical Model for E'valuating Parameters Affecting Water Yields of River Basins." Journal of Geophysical Research, v. 66, pp. 3319-3328 (October, 196I).

4. Hutchinson, J., Manning, H. L., and Farlrother, H. G. "On the Characterization of Tropical Rainstorms in Relation to Runoff and Percolation." Quarterly Journal Royal Meterological Society, v. 84, pp. 250-258 (1958).

5. Kohler, M. A., Linsley, R. K., Jr., and Paulhus, Joseph, L. H. Applied Hydrology, McGraw-Hill Book Company, pp. 689 (1949).

6. Minshall, N. S. "Predicting Storm Runoff on Small Experimental Watersheds." Proceedings, American Society Civil Engineers, v.' 86, No. HY8, pp. 17-38 (August, 1960).

7. Neal, J. H. "Soil and Water Losses as Affected by Rainfall Characteristics." Agricultural Engineering, v. 26, pp. 463-464 (November, 1945).

8. Schiff, Leonard. "Classes and Patterns of Rainfall with Reference to Surface Runoff." American Geophysical Union Transaction, pp. 439-450 (1943).

9. Snedecor, G. W. Statistical Methods, the Iowa State University Press, 5th Edition (1956).

10. Snyder, W. M. "Some Possibilities for Multivariate Analysis in Hydrologic Studies." Paper prepared for presentation at the 42nd Annual Meeting of American Geophysical Union (April 18, 1961).

11. Wischmeier, W. H., Smith, D. D., and Uhland, R. E. "Evaluation of Factors in the Soil-Loss Equation." Agricultural Engineering, v. 39, pp. 458-462 (August, 1958).

12. Young, V. D. "Rainfall-Runoff Relations for Small Watersheds." Agricultural Engineering, v. 29, pp. 212-214 (May, 1948). 


\section{Appendix A}

\section{LIST OF SYMBOLS AND ABBREVIATIONS}

Q Runoff volume (inches)

$\mathrm{P}$ Total rainfall (inches)

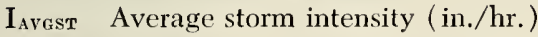

I AVGRP Average rain period intensity (in./hr.)

SL Intensity-Amount-Distribution Index

PI Pattern index

E Energy (foot-tons/acrc-inch)

$\mathrm{E} \cdot \mathrm{I}_{30} \quad$ Energy x 30-minute maximum intensity

I $_{\text {WT1 }}$ Weighted intensity-No. 1-(in./hr.)

$\mathrm{I}_{\text {WT2 }} \quad$ Weighted intensity-No. 2-(in./hr.)

$\mathrm{PI}_{\text {WT }}$ Weighted pattern index

D Duration of storm event (minutes)

r Correlation coefficient

$r^{2} \quad$ Coefficient of determination in linear regression. The fraction of sums of squares of runoff volume due to regression

$\mathrm{R}^{2} \quad$ Coefficient of determination in multiple regression

I Intensity per given time interval (in./hr.)

I2 2-minute maximum intensity (in./hr.)

I5 5-minute maximum intensity (in./hr.)

I 10-minute maximum intensity (in./hr.)

$I_{15} \quad$ 15-minute maximum intensity (in./hr.)

I $_{20}$ 20-minute maximum intensity (in./hr.)

$\mathrm{I}_{30}$ 30-minute maximum intensity (in./hr.)

Iro 60-minute maximum intensity (in./hr.)

I90 90-minute maximum intensity (in./hr.)

$\mathrm{I}_{120}$ 120-minute maximum intensity (in./ $\mathrm{hr}$.)

$\mathrm{I}_{150} \quad$ 150-minute maximum intensity (in./hr.)

$\mathrm{I}_{2+1} \quad$ 240-minute maximum intensity (in./hr.) 


\section{Appendix B}

\section{SAMPLE CALCULATIONS}

A representative storm (Table BI) was selected to illustrate the analytical procedures involved in computing the various rainfall characteristics. The methods, as outlined, are identical to those used for programming the IBM 1620 computer.

\section{Total Rainfall}

$$
\begin{aligned}
& \mathrm{P}={ }_{\mathrm{i}}^{\mathrm{n}} \mathrm{\textrm {Pi }}+\ldots+\mathrm{Pn} \text { where: } \\
& \mathrm{P}=\text { total rainfall } \\
& \mathrm{Pi}=\text { rainfall per time interval }
\end{aligned}
$$

$$
\begin{aligned}
\mathrm{P} & =\sum_{\mathrm{i}=1}^{38} 0.04+0.03+0.06+\ldots \ldots+0.01 \\
& =2.17 \text { inches }
\end{aligned}
$$

\section{Maximum Intensity for Selected Time Intervals}

\section{Procedure:}

1. Compute equivalent one-minute rainfall totals (Col. 2, Table B2).

2. Accumulate one-minute totals (Col. 3, Table B2).

3. Determine the rainfall for the desired time intervals (Cols. 4 through 9, Table B2). Considering the two-minute time interval (Col. 4), the first value is equal to the accumulated rainfall value (Col. 3) at time (Col. 1) equivalent to the time interval of two minutes. Find successive values by taking the succeeding accumulated values, in order, and subtracting the preceding value at the time minus the time interval. The second value, then, is $0.0066-0.0022$; the third $0.0088-0.0044$; and the fourth $0.0111-0.0066$. Continue this procedure for each time interval for the entire storm.

4. By inspection, select the maximum rainfall from columns 4 through 9 for the respective time intervals.

5. Determine the maximum intensity from the relation $I_{t}=P_{i} / t \cdot 60$, where: $I_{t}=$ maximum intensity for selected time interval in inches per hour $\mathrm{P}_{\mathrm{i}}=$ maximum rainfall for time interval

$t=$ time interval in minutes 
Table B1. Sample Storm Event of June 28, 1957, Watershed 115, Coshocton, Оho

\begin{tabular}{|c|c|c|c|c|c|c|c|}
\hline \multirow{2}{*}{$\begin{array}{c}\text { Interval } \\
\text { Number } \\
\text { (i) } \\
\text { (1) }\end{array}$} & \multirow{2}{*}{$\begin{array}{c}\text { Time } \\
(\min .) \\
(2)\end{array}$} & \multirow{2}{*}{$\begin{array}{c}\text { Rainfall } \\
\text { (in.) } \\
(3)\end{array}$} & \multirow{2}{*}{$\begin{array}{c}\text { Intensity } \\
\text { (in./hr.) } \\
(4) \\
\end{array}$} & \multicolumn{2}{|c|}{$\begin{array}{c}\text { Decimal equivalent } \\
\text { of the } \\
\text { percentage of: }\end{array}$} & \multicolumn{2}{|c|}{ Accumulations of: } \\
\hline & & & & $\begin{array}{c}\text { Rainfall } \\
(5)\end{array}$ & $\underset{(6)}{\text { Time }}$ & $\begin{array}{c}\text { Rainfall } \\
(7)\end{array}$ & $\begin{array}{c}\text { Tine } \\
(8)\end{array}$ \\
\hline 1 & 18 & 0.04 & 0.13 & 0.0184 & 0.0731 & 0.0184 & 0.0731 \\
\hline 2 & 2 & 0.03 & 0.90 & 0.0138 & 0.0081 & 0.0322 & 0.0812 \\
\hline 3 & 2 & 0.06 & 1.80 & 0.0276 & 0.0081 & 0.0598 & 0.0893 \\
\hline 4 & 2 & 0.07 & 2.10 & 0.0322 & 0.0081 & 0.0920 & 0.0974 \\
\hline 5 & 2 & 0.04 & 1.20 & 0.0184 & 0.0081 & 0.1104 & 0.1055 \\
\hline 6 & 2 & 0.03 & 0.90 & 0.0138 & 0.0081 & 0.1242 & 0.1136 \\
\hline 7 & 6 & 0.02 & 0.20 & 0.0092 & 0.0243 & 0.1334 & 0.1379 \\
\hline 8 & 10 & 0.04 & 0.24 & 0.0184 & O.0406 & 0.1518 & 0.1785 \\
\hline 9 & 14 & 0.03 & 0.13 & 0.0138 & 0.0569 & 0.1656 & 0.2354 \\
\hline 10 & 6 & 0.02 & 0.20 & 0.0092 & 0.0243 & 0.1748 & 0.2597 \\
\hline 11 & 6 & 0.03 & 0.30 & 0.0138 & 0.0243 & 0.1886 & 0.2840 \\
\hline 12 & 16 & 0.14 & 0.53 & 0.0645 & 0.0650 & 0.2531 & 0.3490 \\
\hline 13 & 2 & 0.01 & 0.30 & 0.0046 & 0.0081 & 0.2577 & 0.3571 \\
\hline 14 & 4 & 0.05 & 0.75 & 0.0230 & 0.0162 & 0.2807 & 0.3733 \\
\hline 15 & 14 & 0.10 & 0.43 & 0.0460 & 0.0569 & 0.3267 & 0.4302 \\
\hline 16 & 4 & 0.03 & 0.45 & 0.0138 & 0.0162 & 0.3405 & 0.4464 \\
\hline 17 & 4 & 0.05 & 0.75 & 0.0230 & 0.0162 & 0.3635 & 0.4626 \\
\hline 18 & 7 & 0.09 & 0.77 & 0.0414 & 0.0284 & 0.4049 & 0.4910 \\
\hline 19 & 5 & 0.04 & 0.48 & 0.0184 & 0.0203 & 0.4233 & 0.5113 \\
\hline 20 & 4 & 0.05 & 0.75 & 0.0230 & 0.0162 & 0.4463 & 0.5275 \\
\hline 21 & 2 & 0.06 & 1.80 & 0.0276 & 0.0081 & 0.4739 & 0.5356 \\
\hline 22 & 3 & 0.05 & 1.00 & 0.0230 & 0.0121 & 0.4969 & 0.5477 \\
\hline 23 & 5 & 0.05 & 0.60 & 0.0230 & 0.0203 & 0.5199 & 0.5680 \\
\hline 24 & 5 & 0.06 & 0.72 & 0.0276 & 0.0203 & 0.5475 & 0.5883 \\
\hline 25 & 5 & 0.05 & 0.60 & 0.0230 & 0.0203 & 0.5705 & 0.6086 \\
\hline 26 & 6 & 0.11 & 1.10 & 0.0506 & 0.0243 & 0.6211 & 0.6329 \\
\hline 27 & 4 & 0.11 & 1.65 & 0.0506 & 0.0162 & 0.6717 & 0.6491 \\
\hline 28 & 6 & 0.24 & 2.40 & 0.1105 & 0.0243 & 0.7822 & 0.6734 \\
\hline 29 & 4 & 0.14 & 2.10 & 0.0645 & 0.0162 & 0.8467 & 0.6896 \\
\hline 30 & 6 & 0.04 & 0.40 & 0.0184 & 0.0243 & 0.8651 & 0.7139 \\
\hline 31 & 8 & 0.09 & 0.68 & 0.0414 & 0.0325 & 0.9065 & 0.7464 \\
\hline 32 & 12 & 0.08 & 0.40 & 0.0368 & 0.0487 & 0.9433 & 0.7951 \\
\hline 33 & 12 & 0.04 & 0.20 & 0.0184 & 0.0487 & 0.9617 & 0.8438 \\
\hline 34 & 8 & 0.04 & 0.30 & 0.0184 & 0.0325 & 0.9801 & 0.8763 \\
\hline 35 & 4 & 0.00 & 0.00 & 0.0000 & 0.0162 & 0.9801 & 0.8925 \\
\hline 36 & 6 & 0.01 & 0.10 & 0.0046 & 0.0243 & 0.9847 & 0.9168 \\
\hline 37 & 10 & 0.02 & 0.12 & 0.0092 & 0.0406 & 0.9939 & 0.9574 \\
\hline 38 & 10 & 0.01 & 0.06 & 0.0046 & 0.0406 & $1.0000^{*}$ & $1.0000^{*}$ \\
\hline
\end{tabular}

Total

246

2.17

Runoff $=1.06$ inches.

${ }^{*}$ Last accumulation rounded to unity. 


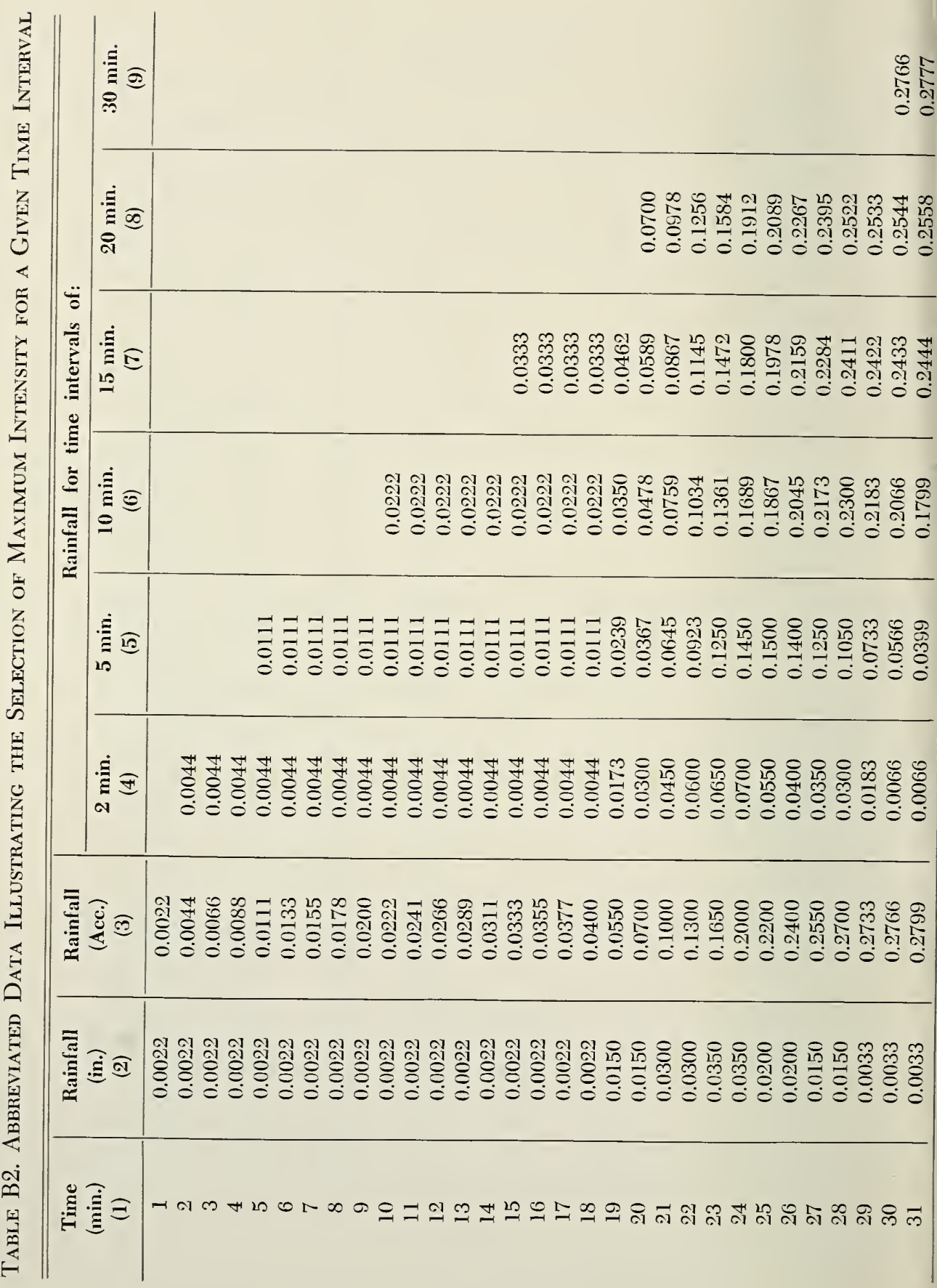




\section{Average Intensity for the Storm Event}

$$
\begin{aligned}
\mathrm{I}_{\mathrm{ATGST}} & =\frac{\mathrm{P}}{\mathrm{T}} \cdot 60 \text { where: } \\
\mathrm{T}=\text { Duration of event in minutes } & \\
\mathrm{I}_{\mathrm{AVGST}} & =\frac{2.17}{246} \cdot 60 \\
& =0.53 \text { inches per hour }
\end{aligned}
$$

\section{Average Intensity for the Rain Period}

$\mathrm{I}_{\text {A GHP }}=\frac{\mathrm{P}}{\mathrm{T}_{0}} \cdot 60$ where:

$\mathrm{T}_{0}=$ duration of event minus duration of periods of zero rainfall 2.17

$$
\begin{aligned}
\mathrm{I}_{\mathrm{AVGH}} & =\frac{2.17}{(246-4)} \cdot 60 \\
& =0.54 \text { inches per hour }
\end{aligned}
$$

\section{Weighted Storm Intensities}

First:

$$
\mathrm{I}_{w \mathrm{~T} 1}=\frac{60}{\mathrm{P}} \stackrel{\mathrm{i}=1}{\mathrm{~N}} \mathrm{I}_{1} \mathrm{P}_{1}+\ldots+\mathrm{I}_{\mathrm{n}} \mathrm{P}_{\mathrm{n}} \text { where }
$$

$I_{1}=$ intensity per time interval in inches per hour

$$
\begin{aligned}
\mathrm{I}_{\mathrm{WT} 1} & =\frac{60}{2.17} \mathrm{i}_{\mathrm{i}=1}^{38}(0.13 \times 0.04)+(0.90 \times 0.03)+\ldots+(0.06 \times 0.01) \\
& =1.06 \text { inches per hour }
\end{aligned}
$$

Second:

$\mathrm{I}_{\text {w } \mathrm{T}:}=\frac{60}{4} \underset{k=1}{\stackrel{n}{=}} \frac{\mathrm{P}_{\mathrm{p}}}{t_{\mathrm{k}}}+\ldots+\frac{\mathrm{P}_{\mathrm{p}}}{\mathrm{t}_{\mathrm{n}}}$ where:

$P_{p}=$ rainfall per partitioned time interval

$t_{\mathrm{k}}=$ duration of storm per interval in minutes

$$
\begin{aligned}
\mathrm{I}_{\mathrm{W} 2} & =\frac{60}{4} \underset{\mathrm{k}=1}{\mathrm{~s}} \frac{0.5425}{85.14}+\frac{0.5425}{50.36}+\frac{0.5425}{28.68}+\frac{0.5425}{81.82} \\
& =0.64 \text { inches per hour }
\end{aligned}
$$

\section{Intensity-Amount-Distribution Index}

Procedure:

1. Plot rainfall histogram (Figure B1) using data from Table Bl. 
2. Construct base intensity lines using values given on page 26 (dashed lines on Figure $\mathrm{BI}$ ).

3. Compute the area under that portion of the histogram above the base intensities, noting that time must be corrected to hours (amount above).

4. Plot logarithm of the "amount above" versus base intensity in inches per hour.

5. Compute the line of best fit by the method of least squares and determine the slope.

\section{Pattern Index}

\section{Procedure:}

1. Determine the decimal equivalent of the percentage of rainfall and time. (Cols. 5 and 6, Table B1). Accumulate these values in Cols. 7 and 8.

2. Plot Figure $\mathrm{B} 2$ using Cols. 7 and 8.

3. Determine the area under the curve of Figure B2 by summing the trapozoidal areas between time intervals as follows:

$$
\begin{aligned}
& \mathrm{PI}=\sum_{\mathrm{i}=1}^{\mathrm{n}} \mathrm{b}_{\mathrm{i}}\left(\frac{\mathrm{H}_{1}}{2}+\mathrm{X}_{1-1}\right)+\cdots+\mathrm{b}_{\mathrm{n}}\left(\frac{\mathrm{H}_{\mathrm{n}}}{2}+\mathrm{X}_{\mathrm{n}-1}\right) \text { where: } \\
& \mathrm{b}=\text { base of triangle or rectangle along abscissa (Col. 6) } \\
& \mathrm{H}=\text { height of triangle along ordinate (Col. 5) } \\
& \mathrm{X}=\text { height of rectangle along ordinate (Col. } 7) \\
& \mathrm{X}_{1-1}=0 \text { when } \mathrm{i}=1 \text { ) } \\
& \mathrm{PI}=\underset{\mathrm{i}=1}{38} 0.0731\left(\frac{0.0184}{2}+0.0000\right)+0.0081\left(\frac{0.0138}{2}+0.0184\right)+ \\
& 0.0081\left(\frac{0.0276}{2}+0.0322\right)+\ldots+0.0406\left(\frac{0.0046}{2}+0.9939\right)=0.4982
\end{aligned}
$$

\section{Weighted Pattern Index}

$$
\begin{aligned}
\mathrm{PI}_{\text {KT }} & =\sum_{i=1}^{n} b_{1} \mathrm{I}_{1}\left(\frac{\mathrm{H}_{1}}{2}+\mathrm{X}_{1-1}\right)+\cdots+\mathrm{b}_{\mathrm{n}} \mathrm{I}_{\mathrm{n}}\left(\frac{\mathrm{H}_{\mathrm{n}}}{2}+\mathrm{X}_{\mathrm{n}-1}\right) \\
\mathrm{PI}_{\mathrm{KT}} & =\sum_{\mathrm{i}=1}^{38} 0.0731 \times 0.13\left(\frac{0.0184}{2}+0.0000\right)+0.0081 \times 0.90 \\
& \left(\frac{0.0138}{2}+0.0184\right)+0.0081 \times 1.80\left(\frac{0.0276}{2}+0.0322\right) \\
& +\cdots+0.0406 \times 0.06\left(\frac{0.0046}{2}+0.9939\right) \\
& =0.50
\end{aligned}
$$




\section{Total Storm Energy}

$$
\begin{aligned}
& E=\sum_{i=1}^{n} P_{1} \quad\left(916+143.7499 I_{n} I_{1}\right)+\cdots+P_{n}\left(916+143.7499 I_{n} I_{n}\right) \\
& \text { where: } \\
& \mathrm{LOG}_{10} \\
& -(316)=143.7499 \\
& \text { ln } \\
& \mathrm{E}=\underset{\mathrm{i}=1}{\mathrm{~s}=1} 0.04(916+143.7499 \ln (0.13))+\cdots+0.01 \\
& (916+143.7499 \ln (0.06))=1912.14 \text { foot-tons per acre }
\end{aligned}
$$

\section{Total Energy x 30-minute Maximum Intensity}

$$
\begin{aligned}
\mathrm{E} \cdot \mathrm{I}_{30} & =\mathrm{E}\left(\mathrm{I}_{30}\right) \\
\mathrm{E} \cdot \mathrm{I}_{30} & =1912.14 \times 1.42 \\
& =2715
\end{aligned}
$$

\section{Storm Duration}

The duration is equal to the total storm duration.

$\mathrm{D}=246$ minutes (Table B1).

\section{Storm Runoff}

The storm runoff was determined from the original hydrograph as defined under sampling procedure (Table $\mathrm{B} 1, \mathrm{Q}=1.06$ inches).

(Turn page for Figures B1 and B2) 


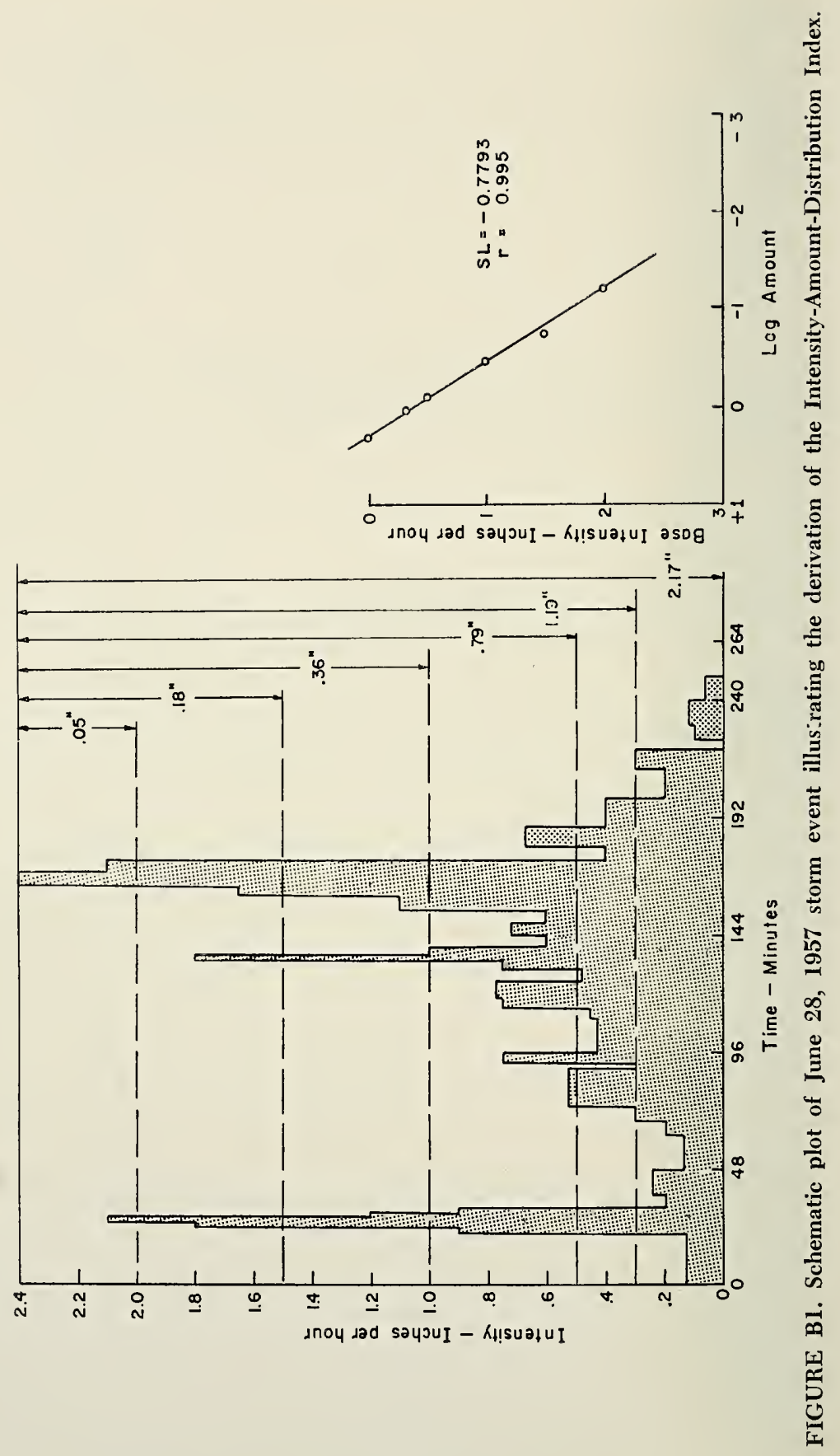




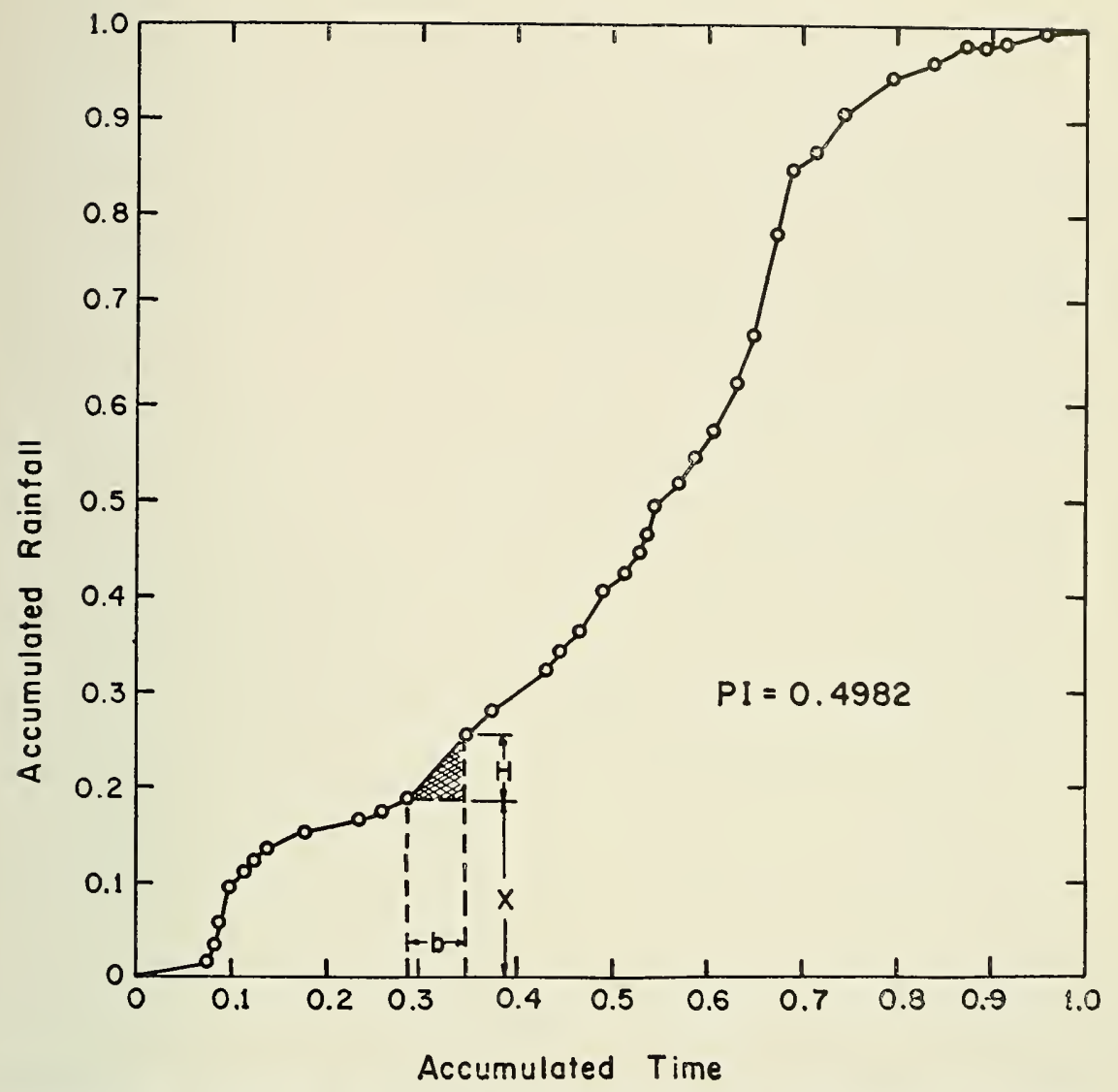

FIGURE B2. Schematic plot of June 28, 1957 storm event illustrating the derivation of the Pattern Index. 


